\title{
ANALISIS KANDUNGAN YODIUM DALAM GARAM BERYODIUM PADA WADAH PENYIMPANAN PLASTIK DAN KACA SELAMA 6 HARI PENYIMPANAN
}

\author{
Analysis of Iodium Content in Salt Iodization in Plastic and Glass Storage Containers \\ for 6 Days of Storage
}

\author{
Nurjaya, Wery Aslinda, Ni Sayu Kadek Sri Astuti \\ Poltekkes Kemenkes Palu \\ (jayajastal@yahoo.com, 082194089170)
}

\begin{abstract}
ABSTRAK
Setiap tahun terdapat 39 juta bayi baru lahir beresiko memiliki kapasitas intelektual rendah akibat defisiensi yodium. Terdapat 5\% ibu hamil yang kadar TSH dan TPO-Abnya meningkat. Konsekuensi defisiensi yodium dapat dihindari jika pada saat hamil ibu sejak awal mengkonsumsi yodium secara adekuat. Sumber yodium yang tersedia dan cukup murah adalah garam yang difortifikasi yodium. Namun, waktu penyimpanan, kondisi penyimpanan, dan jenis garam berpengaruh terhadap penurunan kandungan yodium dalam garam beryodium. Tujuan penelitian untuk mengetahui kandungan iodium pada garam beryodium dengan berbagai wadah penyimpanan selama penyimpanan 6 hari. Jenis penelitian ini merupakan penelitian deskriptif. Sampel garam diambil secara acak di toko kelontong dengan merk dagang yang paling banyak digunakan konsumen di kota Palu dan sekitarnya. Wadah yang digunakan adalah wadah plastik dan wadah kaca. Setiap wadah dibagi dua, ada wadah transparan dan ada wadah yang tidak transparan (dibungkus). Penyimpanan dilakukan selama 6 hari dengan analisa kandungan yodium garam dilakukan pada hari ke 0 , hari ke-2, hari ke-4 dan hari ke-6. Hasil penelitian menunjukan bahwa baik wadah plastik maupun wadah kaca, terdapat penurunan kandungan yodium. Rata-rata persentase penurunan kandungan yodium terbesar terjadi pada penyimpanan dalam wadah plastik dan kaca yang transparan $(9,49 \%$ dan $4,75 \%)$. Sedangkan pada wadah yang tidak transparan rata-rata penurunan kandungan yodiumnya sebesar 4,99\% pada wadah plastik dan 3,18 \% pada wadah kaca. Persentase penurunan kandungan yodium terbesar setiap dua hari penyimpanan terdapat pada garam yang disimpan dalam wadah plastik transparan yakni rata-rata sebesar 4,77\%. Kesimpulan; Penyimpanan garam beryodium yang terbaik adalah dalam wadah kaca yang tidak transparan.
\end{abstract}

\section{Kata kunci : Kandungan Iodium, Garam Beryodium, Wadah Penyimpanan}

\section{ABSTRACT}

Every year there are 39 million of infant newborn at risk of being born with low intellectual capacity due to iodine deficiency. Meanwhile, there are 5 percen of pregnant women who have increased TSH and TPO-Ab level.The consequences of Iodine deficiency can be prevented if pregnant women in adequate iodine intake early. Abundant and inexpensive source of iodine is salt iodization. Unfortunatelly, iodine concentration in salt iodization can be decreased due to time and conditions of storage, and type of salt. The aim of this study is to determine iodine content in Salt iodization that stored in different containers for six days of storage. The type of study was descriptive study. Sample is salt iodization were obtained from the grocery store by taking randomly and brands that are widely used in Palu city and its surroundings. Storage container of salt iodization consist of two namely plastic and glass jar. Each container consist of transparent and non transparent jars. Storage of sample is carried out for six days and analysis of iodine content was carried out on day 0 , day 2, day 4 and day 6 of storage. The result of study showed that both glass and plastic container decreased iodium content in salt. The largest median of percentage reduction in iodine content occurred in transparent plastic and glass container, in 9,49 and 4,74\% respectively. However, median of percentage reduction in non-transparent plastic and glass container, in 4,99 and 3,18\%, respectively. For 2 days of storage, the largest median of percentage reduction in iodine content found in transparent plastic container which is $4,77 \%$. Conclusion: The best storage of iodization salt is it in non-transparent container.

Keywords : Iodine content, iodized salt, storage container 


\section{PENDAHULUAN}

Setiap tahun, 39 juta bayi baru lahir beresiko mempunyai kapasitas intelektual rendah akibat defisiensi yodium. Resiko memiiiki IQ di bawah persentil ke 25 (rendah) pada anak usia sekolah yang kekurangan Iodium (EIU < $100 \mu \mathrm{g} / \mathrm{L})$ sebesar 1,83 kali dibandingkan anak yang cukup Iodium (EIU > $150 \mu \mathrm{g} / \mathrm{L}$ ). Namun demikian, resiko segmen anak usia sekolah tidak mencerminkan resiko segmen untuk ibu hamil dan wanita usia subur. Setiap tahun, terdapat 5\% ibu hamil yang kadar TSH dan TPO-Abnya meningkat, dan berlanjut menjadi hipotiroid klinik. Dalam 1000 wanita hamil, terdapat 3-5\% diperkirakan mengalami overhipotiroid dan 2-3\% mengalami hipotiroid subklinik $^{(1)}$.

Defisiensi Iodium menyebabkan produksi hormon tiroid (tiroksin, triioditironin) oleh kelenjar tiroid berkurang. Kekurangan hormon tiroid mengganggu proses yang bergantung pada hormon tiroid termasuk proses metabolik dan proses fisiologik. Periode kritis kebutuhan Iodium ialah sebelum trimester kedua berakhir. Periode ini, janin sangat membutuhkan hormon tiroid untuk pertumbuhan otak. Dengan demikian, defisiensi yodium pada periode ini menyebabkan gangguan pertumbuhan dan perkembangan otak. Manifestasi klinik ialah gangguan saraf, kecerdasan tidak optimal, keguguran dan kelahiran prematur, hipotiroidisme kongenital, retardasi mental sampai yang terberat kretin endemik. Manifestasi ini dikenal dengan Gangguan Akibat Kekurangan Yodium (GAKY) $)^{(2)}$. GAKY pada anak dapat menyebabkan terjadinya penurunan kecerdasan anak 15-20 poin dibandingkan dengan anak yang sehat ${ }^{3}$.

Hasil Riset Kesehatan Dasar (Riskesdas) 2007 mengungkapkan bahwa median EIU (Ekskresi Iodium Urin) anak sekolah adalah sebesar 242 mg/L (kecukupan 120 mg/L); Proporsi EIU (ekskresi iodium urin) di atas $300 \mathrm{mg} / \mathrm{L}$ (berlebih) sebesar 21,9 \% dan proporsi kurang dari $100 \mathrm{mg} / \mathrm{L}$ (kurang yodium) sebesar $12,9 \%$. Bahkan proporsi kabupaten yang median EIU (ekskresi iodium urin) anak sekolahnya di atas $300 \mathrm{mg} / \mathrm{L}$ mencapai $35,4 \%$. Sementara proporsi rumah tangga yang mengkonsumsi garam beryodium (sumber utama pasokan konsumsi yodium) sekitar 70\%. Kriteria WHO aman dari defisiensi yodium bagi suatu wilayah jika $90 \%^{(4)}$.

Konsekuensi defisiensi iodium dapat dicegah bilamana ibu hamil memperoleh Iodium secara adekuat. Sumber Iodium yang tersedia banyak dan relative murah harganya adalah garam yang difortifikasi Iodium atau lebih dikenal dengan garam Iodium untuk semua (Universal Salt Iodization) ${ }^{(1)}$.

Selama penyimpanan, garam beryodium dapat mengalami kerusakan terutama penyimpanan di gudang atau di warung. Garam yang tidak ditutup dan terpapar sinar matahari dapat rusak dan berkurang kadar yodiumnya. Garam beryodium dalam kemasan plastik yang disimpan pada suhu $25-27^{\circ} \mathrm{C}$ dengan kelembaban $70-80 \%$, tahan selama 6 bulan. Kandungan yodium akan menyusut sebanyak $7 \%$ setelah 6 bulan $^{(5)}$.

$$
\text { Hasil penelitian Wafiyah }
$$
menunjukkan bahwa berkurangnya kandungan 
yodium pada garam dapat disebabkan oleh beberapa faktor seperti tempat penyimpanan, cara menyimpan, lama penyimpanan dan lokasi penyimpanan garam $^{(5)}$. Sedangkan hasil penelitian Anthony dan Hannah (2017) menunjukkan bahwa dari 4 jenis wadah penyimpanan yang berbeda, yakni cup platik kuning, botol mayoinnase transparan, kaleng susu, dan kantung plastik transparan, ternyata penyimpanan garam beryodium yang paling baik adalah dalam cup plastik kuning dan dalam kaleng $\operatorname{susu}^{(6)}$. Tujuan penelitian ini adalah untuk mengetahui kandungan iodium pada garam beryodium dengan berbagai wadah penyimpanan selama penyimpanan 6 hari

\section{METODE PENELITIAN}

Jenis Penelitian ini adalah penelitian Deskriptif untuk memperoleh gambaran kandungan Iodium pada garam beryodium dengan berbagai wadah penyimpanan selama penyimpanan 6 hari. Penelitian ini dilaksanakan tahun 2017. Sampel garam beryodium yang digunakan dalam penelitian ini adalah garam dengan merk dagang "Kapal" karena merk dagang ini yang paling popular digunakan di kota Palu dan sekitarnya. Wadah penyimpanan terdiri dari 4 jenis yakni toples kaca transparan, toples kaca tidak transparan (dibungkus), toples plastik transparan dan toples plastik tidak transparan (dibungkus). Sampel garam dianalisis kandungan iodiumnya pada hari ke-0, hari ke.-2, hari ke-4 dan hari ke-6 selama masa penyimpanan. Analisis kandungan Iodium di laboratorium menggunakan metode Titrimetri dengan Analisis Univariat.

\section{HASIL}

Tabel 1 berikut ini menggambarkan rata-rata penyusutan/penurunan kandungan Iodium dalam garam beryodium yang disimpan dalam 4 jenis penyimpanan. Analisis kandungan Iodium dilakukan mulai hari ke-0 penyimpanan hingga hari ke-6 penyimpanan dan dilakukan analisis setiap 2 hari penyimpanan. Penyimpanan garam beryodium dilakukan dalam ruangan yang sama dengan suhu berkisar $28^{\circ} \mathrm{C}$ dengan kelembaban $87 \%$.

Tabel 1 Kandungan Iodium pada Garam Beryodium Pada Wadah Plastik dan Kaca Selama 6 Hari Penyimpanan

\begin{tabular}{|c|c|c|c|c|c|c|c|c|c|c|c|}
\hline \multirow{2}{*}{ No } & & \multirow{2}{*}{ Jenis Wadah } & \multicolumn{8}{|c|}{$\begin{array}{c}\text { Kandungan iodium berdasarkan waktu } \\
\text { penyimpanan (ppm) }\end{array}$} & \multirow{2}{*}{$\begin{array}{c}\% \text { Rata-rata } \\
\text { Penyusutan } \\
\text { Kandungan Iodium } \\
\text { Hingga Hari ke-6 }\end{array}$} \\
\hline & & & \multicolumn{2}{|c|}{ hari ke 0} & \multicolumn{2}{|c|}{ Hari ke 2} & \multicolumn{2}{|c|}{ Hari ke 4} & \multicolumn{2}{|c|}{ Hari ke 6} & \\
\hline \multirow{6}{*}{ B } & & & & & & & & & & & \\
\hline & 1 & Tidak Transparan & 55,5 & MS & 53,7 & MS & 52,9 & MS & 51,6 & MS & 4,99 \\
\hline & 2 & Transparan & 55,5 & MS & 52,9 & MS & 50,2 & MS & 47,6 & MS & 9,49 \\
\hline & & dah Kaca & & & & & & & & & \\
\hline & 1 & Tidak Transparan & 55,5 & MS & 54,6 & MS & 53,7 & MS & 52,9 & MS & 3,18 \\
\hline & 2 & Transparan & 55,5 & MS & 53,7 & MS & 52,9 & MS & 52,0 & MS & 4,75 \\
\hline
\end{tabular}

Sumber : Data Primer, 2017

Keterangan:

MS = Memenuhi Persyaratan (Kandungan Iodium oleh pemerintah) 


\section{PEMBAHASAN}

Berdasarkan Kepmenkes Nomor 165/Menkes/SK/II/1986 tentang Persyaratan garam beryodium, hingga saat ini regulasi yang ada masih menetapkan bahwa kandungan Iodium dalam garam beryodium hasil dalam negeri adalah sebesar $40-50$ ppm $\mathrm{KIO}_{3}$ pada tingkat produksi sedangkan kandungan Iodium pada tingkat distribusi adalah sebesar 30-50 ppm $\mathrm{KIO}_{3}$.

Hasil analisa di laboratorium menunjukan bahwa kandungan Iodium pada garam beryodium yang disimpan dalam wadah plastik mengalami penurunan yang lebih besar dibanding garam beryodium yang disimpan dalam wadah yang terbuat dari kaca. Hasil analisa laboratorium juga menunjukkan bahwa wadah yang tidak transparan memberikan penurunan Iodium yang lebih kecil dibanding wadah yang transparan. Dari 4 jenis penyimpanan yang dilakukan, rata-rata persentase penurunan kandungan Iodium terkecil terdapat pada garam yang disimpan dalam wadah kaca yang tidak transparan $(3,18 \%)$ sedang rata-rata persentase penurunan kandungan Iodium terbesar terjadi pada garam yang disimpan dalam wadah plastik transparan $(9,49 \%)$. Rata-rata penurunan kandungan Iodium selang 2 hari penyimpanan pada wadah plastik tidak transparan sebesar 1,9\%, sedangkan rata-rata penurunan kandungan Iodium selama 2 hari penyimpanan pada wadah plastik transparan sebesar 4,77\%. Namun dari semua jenis penyimpanan tersebut, kandungan Iodium dalam garam masih menunjukkan batas yang dipersyaratkan yakni $>30 \mathrm{ppm}$.

Adanya zat-zat pengotor dalam garam seperti $\mathrm{Fe}, \mathrm{Pb}, \mathrm{Ca}, \mathrm{Mn}$ dan $\mathrm{Sr}$ akan mempercepat terjadinya pelepasan $\mathrm{I}_{2}$. Iodium bebas akan menguap keudara. Kemasan selama penyimpanan garam akan mempengaruhi kandungan Iodium. Selain itu suhu dan kelembaban udara juga berpotensi untuk mengurangi kandungan Iodium dalam garam 7 . Reaksi kimia Iodium berlangsung menurut reaksi kinetika. Laju reaksi penurunan kandungan Iodium bertambah dengan bertambahnya waktu penyimpanan garam beryodium $^{(6)}$.

Bahan plastik disusun oleh suatu polimer. Polimer memiliki sifat yang mudah bereaksi terhadap panas. Berdasarkan sifat termal polimer dapat dibedakan atas polimer termoplastik (tidak tahan panas, seperti plastik) dan polimer termosting (tahan panas, seperti melamin). Jenis plastik ini tidak memiliki ikatan silang antar rantai polimernya, melainkan dengan struktur molekul linear atau bercabang. Plastik ini dianjurkan hanya boleh gunakan satu kali saja karena bahan ini gampang terurai dengan adanya panas, cahaya dan tekanan mekanik yang menimbulkan udara yang terperangkap. Polimer memiliki beberapa kelemahan diantaranya kapasitas absorpsi yang terbatas, karakteristik fisik yang kurang kuat, tidak stabil terhadap perubahan suhu dan $\mathrm{pH}^{(8)}$. Karaktersitik polimer inilah yang memungkinkan terjadinya penurunan kandungan Iodium yang lebih besar dalam wadah plastik. 
Bahan kaca memiliki karakteristik yang "inert" terhadap bahan makanan (tidak bereaksi) dan beberapa gelas kualitas tinggi tahan terhadap suhu sehingga bahan gelas merupakan wadah yang aman untuk penyimpanan bahan makanan termasuk $\operatorname{garam}^{(9)}$.

\section{KESIMPULAN DAN SARAN}

Dari 4 jenis penyimpanan yang dilakukan, rata-rata persentase penurunan kandungan Iodium terkecil terdapat pada garam yang disimpan dalam wadah kaca yang tidak transparan $(3,18 \%)$ sedang rata-rata persentase penurunan kandungan Iodium terbesar terjadi pada garam yang disimpan dalam wadah plastik transparan $(9,49 \%)$. Ratarata penurunan kandungan Iodium selang 2 hari penyimpanan pada wadah plastik tidak transparan sebesar $1,9 \%$, sedangkan rata-rata penurunan kandungan Iodium selama 2 hari penyimpanan pada wadah plastik transparan sebesar 4,77\%. Namun dari semua jenis penyimpanan tersebut, kandungan Iodium dalam garam masih menunjukkan batas yang dipersyaratkan yakni > 30 ppm, selama 6 hari masa penyimpanan. Dari hasil penelitian ini perlu dilanjutkan dengan penelitian selanjutnya yang mengkaji rerata penurunan kandungan Iodium dalam garam sejak produksi pertama kali.

\section{DAFTAR PUSTAKA}

1. Budiman B. Status Iodium Indonesia Saat Ini: Perlunya Penajaman Sasaran. Gizi Indon 2012; 35 (1) : 5 - 9

2. Kemenkes RI. 2010. Pedoman Pelaksanaan Pemantauan Garam Beryodium di Tingkat Masyarakat. Kemenkes RI: Jakarta

3. Izati, Mahmudiono. Pola Konsumsi Makanan Sumber Yodium dan Goitrogenik dengan
GAKY pada Anak Usia Sekolah di Ponorogo. Amerta Nutrt 2017; 88 - 97

4. Kemenkes RI, Badan Litbangkes RI 2010, Laporan Hasil Riset Kesehatan Dasar tahun 2007. Kemenkes RI: Jakarta

5. Mafiyah. Muwakhidah. Penyimpanan Garam, Kualitas Yodium Dan Kadar Yodium Dalam Urin Pada Ibu Hamil Di Puskesmas Ampel II Boyolal. (Internet) 2013; 6 (2). Available from : http://www.ejurnal.com/2015/05/penyimpanan-garamkualitas-yodium-dan.html

6. Anthony A K, Hannah K. The Effect of Storage Conditions on The Levels of Iodine in Iodized Salt. Imperial Journal of Interdiciplinary Research 2017; 3 (1)

7. Permatasari. Stabilitas Kadar Iodium dalam Garam Fortifikasi Kalium Iodida (KI) menggunakan NaFeEDTA. Darussalam Nutrition Journal Mei 2017; 1 (1) : 8 - 15

8. Isananto, W. 2014. Mekanisme Reaksi Dekradasi Plastik Oxo-Degradabel. (Internet) (http://prosiding.bbkkp.go.id/index.php/SKKP /article/download/27/26)

9. Indraswati D. 2017. Pengemasan Makanan. Forum Ilmiah Kesehatan: Jakarta 